\title{
Lipid oxidation in meat: mechanisms and protective factors - a review
}

\author{
Ana Beatriz AMARAL ${ }^{1}$, Marcondes Viana da SILVA², Suzana Caetano da Silva LANNES ${ }^{1 *}$
}

\begin{abstract}
Lipid oxidation in meats is a process whereby polyunsaturated fatty acid react with reactive oxygen species leading to a series of secondary reactions which in turn lead to degradation of lipids and development of oxidative rancidity. This process is one of the major factors responsible for the gradual reduction of sensory and nutritional quality of meats, thus affecting consumer acceptance. Therefore, the control and minimization of lipid oxidation in meat and meat products is of great interest to the food industry. In view of this, some technologies have been developed, such as vacuum packaging, modified atmosphere, and use of antioxidants. The aim is understanding the lipid oxidation mechanisms responsible for sensory and nutritional quality reduction in meat and meat products and identify the most effective methods to control this process. Lipid oxidation in meat can be controlled using different strategies, such as animal dietary supplements, addition of antioxidants, processing, and the use of special packaging. Better results can be obtained by using synergistic strategies and focusing attention on food safety and to prevent negative effects to other sensory properties.
\end{abstract}

Keywords: lipids; meat products; antioxidants.

Practical Application: Lipid oxidation is an important issue in many food studies, and we discuss some aspects that influence the lipid oxidation of meat.

\section{Introduction}

Lipids are important components of all types of meat and are responsible for many desirable characteristics of meats. They are important for the flavor and aroma profile of meats and contribute to tenderness and juiciness.

Lipid oxidation is the main process responsible for the quality deterioration of meat and meat products by reducing shelf life (Min \& Ahn, 2005). Lipid oxidation affects color, texture, nutritional value, taste, and aroma leading to rancidity, wish is responsible for off-flavors and unacceptable taste, which are important reasons for consumer rejection (Lima et al., 2013). Considering that "quality" and "health" are known as some of the most important factors that influence food choice and that appearance, color, texture, taste, and aroma are the key quality attributes that affect meat acceptance, the control, or at least minimization, of the lipid oxidation process is of great interest to the food industry (Brøndum et al., 2000).

The development of oxidative rancidity in meat begins at the time of slaughter, when blood flow is interrupted, and the metabolic processes are blocked (Lima et al., 2013). It is a rather complex process in which unsaturated fatty acids react with molecular oxygen via free radical chain-forming peroxides. The first auto-oxidation is followed by a series of secondary reactions, which lead to lipid degradation and the development of oxidative rancidity products (Min \& Ahn, 2005). Oxidation begins with phospholipids and is catalyzed by heme proteins, such as hemoglobin and myoglobin, cytochromes, free iron, enzymes, and sodium chloride. Phospholipids are found in cell membranes and are rich in polyunsaturated fatty acids; therefore, these are very susceptible to oxidation (Brøndum et al., 2000).

The nature and relative proportions of compounds formed by lipid oxidation depend on the characteristic lipid composition of the slaughtered animal, and they also depend on many other factors such as processing methods, storage conditions, types of ingredients, and presence and concentrations of pro- or antioxidants. It is important to mention that the animal lipid profile also varies according to a number of factors, including animal diet and lifestyle (Min \& Ahn, 2005).

A matter that deserves close attention is related to pre-prepared products. Cooked meats are even more susceptible to lipid oxidation than raw meat (Byrne et al., 2002) because higher temperatures lead to the release of oxygen and heme, iron, thereby, inducing production of free radicals. Thus, there is undesirable development of off-odors and off-flavors, which usually become apparent within $48 \mathrm{~h}$ at $4^{\circ} \mathrm{C}$. These flavors become particularly noticeable after reheating the meat and are referred to as WOF (warmed-over flavor) (Byrne et al., 2002). This poses a major challenge for the industry, since consumers have increasingly valued convenience products that are ready to eat, and at the same time they value taste and appearance (Min \& Ahn, 2005; Font-I-Furnols \& Guerrero, 2014) 
Aiming at offering products with desirable characteristics and stability, some technologies have been developed seeking to reduce lipid oxidation and to increase shelf-life of these products, such as vacuum packaging, modified atmosphere, and use of antioxidants. Natural products of animal origin are currently receiving more attention, since the addition of substances such as butylated hydroxytoluene (BHT), butylated hydroxyanisole (BHA), and tert-butylhydroquinone (TBHQ) in food products is strictly limited. Antioxidants can be added directly into the product or can be added to the animal feed (Lima et al., 2013).

Considering the large number of potential protective factors against lipid oxidation, this review aims to analyze and discuss possible strategies to control and minimize lipid oxidation in meat and meat products.

The objectives of this review were to display the lipid oxidation mechanisms responsible for sensory and nutritional quality reduction in meat and meat products and to identify the most effective methods to control this process.

\subsection{Meat and meat products}

Meat and meat products are good sources of protein with high biological value, fat-soluble vitamins, minerals, and bioactive compounds. Pork meat is the most widely eaten meat in the world, followed by poultry, beef, lamb, and goat meats (Font-I-Furnols \& Guerrero, 2014). Meat products result from various methods of processing of fresh meat, aiming to develop desirable products and to reduce perishability during transport and storage.

Meat and meat products are complex systems of rich nutritional composition, which makes them very susceptible to chemical and bacterial spoilage. Lipid oxidation is the major cause of chemical deterioration in meat, and it probably starts in the muscles of the living animal and intensifies after slaughter due to the changes in the environment and the loss of intrinsic antioxidant capacity. The rate of lipid oxidation in meat intended for consumption depends on several factors, ranging from the environment where the animal was raised to the storage conditions of cooked meat (Shah et al., 2014). The mechanisms of the factors involved in lipid oxidation in meat and meat products are discussed next.

\subsection{Lipid oxidation and its mechanisms}

Lipid oxidation is a major cause of the deterioration of fatty tissues in meats. It is a spontaneous and inevitable process that directly affects meat commercial value and products (Lima et al., 2013). Lipids are one of the most chemically unstable food components that participate in oxidative reactions (Min \& Ahn, 2005) induced by several factors through quite complex mechanisms. The major known factors involved in these reactions include the type of lipid structure and its environment. The degree of the unsaturation in fatty acids, exposure to light and heat, and the presence of molecular oxygen, pro-oxidant and antioxidant components are factors affecting the oxidative stability of lipids (Lima et al., 2013).
Natural components found in muscle tissue such as iron, myoglobin $(\mathrm{Mb})$, hydrogen peroxide $\left(\mathrm{H}_{2} \mathrm{O}_{2}\right)$, and ascorbic acid can cause lipid oxidation, acting as catalysts or promoting the formation of reactive oxygen species (ROS). Oxidative reactions can also be initiated by physical factors such as radiation and light. Therefore, in biological systems, lipids undergo oxidation via three main reactions: photo-oxidation, enzymatic oxidation, and autoxidation (Wójciak \& Dolatowski, 2012).

Photo-oxidation is facilitated by radiant energy, mainly ultraviolet radiation, in the presence of sensitizers such as myoglobin, and it involves the participation of radical reactions resulting in the formation of hydroperoxides different from those formed in the absence of light and sensitizers (Lorenzo \& Gomez, 2012).

Autoxidation is a very complex chemical phenomenon that involves self-programming radical reactions and depends on catalytic action (temperature, $\mathrm{pH}$, metal ions, and free radicals). The overall mechanism of oxidation includes three steps:

1- Disappearance of oxidation substrates such as oxygen and fatty acids.

2- Formation of peroxides and hydroperoxides, the primary products of oxidation.

3- Formation of secondary products such as aldehydes, alcohols, and other volatile and nonvolatile compounds (Wójciak \& Dolatowski, 2012).

On the other hand, enzymatic oxidation is catalyzed by lipoxygenase, enzymes that oxidize fatty acids leading to the addition of oxygen to the hydrocarbon chain. The result is the formation of peroxides and hydroperoxides with conjugated double bonds, which can undergo different degenerative reactions, forming several products (Lorenzo \& Gomez, 2012; Lima et al., 2013).

\section{Mechanism}

Lipid Oxidation (LOx) is defined as a chain reaction of free radicals and consists of three stages: initiation, propagation, and termination. In the course of the reaction, there is a free radical that reacts with the hydrocarbon chain of the fatty acid forming peroxides, which, in turn, react with other hydrocarbon chains abstracting hydrogens originating hydroperoxides. The carbon chain, from which the hydrogens have been abstracted, will act as new peroxide, perpetuating the cycle (Estevez, 2015; Lima et al., 2013).

Free radicals are highly reactive species that have one or more free electrons, which can exist independently for a short period. Some examples of these reactive oxygen molecules are: hydroxyl radical ( $\mathrm{HO} \bullet)$, organic compound oxygen radicals, peroxyl (ROO•) and alkoxyl (RO•) radicals, superoxide radical $\left(\mathrm{O}_{2}^{-}\right)$and its radical conjugate hydroperoxide acid $\left(\mathrm{HO}_{2}\right)$, and singlet oxygen $\left(\mathrm{O}_{2}^{1}\right)$. These reactive oxygen molecules can be produced intentionally or accidentally. In biological systems, they are produced during the normal aerobic metabolism. Mitochondria consume molecular oxygen reducing it by sequential 
steps to produce ATP and $\mathrm{H}_{2} \mathrm{O}$. During this process, $\mathrm{O}^{1}{ }_{2}, \mathrm{H}_{2} \mathrm{O}_{2}$, $\mathrm{HO} \bullet$ are formed as unwanted by-products. Meanwhile, the cells that protect the body (phagocytes) deliberately generate $\mathrm{O}^{1}{ }_{2}$ and $\mathrm{H}_{2} \mathrm{O}_{2}$ to inactivate bacteria and viruses (Lima et al., 2013).

During the initiation stage of LOx, a hydrogen atom $(\mathrm{H} \bullet)$ is abstracted from a neighbor carbon to a double bond in an unsaturated fatty acid (RH) forming the alkyl $\mathrm{R} \cdot(\mathrm{E} 1)$ radical (Srinvasan et al., 2008; Van Hecke et al., 2017):

$R: H+O:: O+$ Initiator $\rightarrow R \bullet($ alkyl radical $)+H O O \bullet$

This alkyl radical can react with a molecular oxygen and generate various radical species, such as the peroxyl (ROO•) radical (E2). These radicals, in turn, may find stability in the subsequent propagation stage by abstracting a hydrogen atom from another susceptible molecule, such as an adjacent $\mathrm{RH}$ forming a lipid hydroperoxide (ROOH) and a new R• (E3) (Min \& Ahn, 2005).

$R \cdot+O 2+R O O \bullet$

$R O O \bullet+R H \rightarrow R O O H+L \bullet$

These propagation mechanisms may occur up to 100 times before two R $\bullet$ combine and terminate the process. Radical species formed during the process may be stabilized into non-radical compounds. The peroxides that are commonly formed as LOX primary products can subsequently undergo scission to form lower molecular weight volatile and non-volatile compounds (secondary LOX products) such as carbonyls, alcohols, hydrocarbons, and furans. Among these, aldehydes are one of the most abundant products found in meat, such as hexanal malondialdehyde (MDA) and 4-hydroxy-2-trans-nonenal (Estevez, 2015).

Oxidative deterioration takes place according to the mechanisms described above as soon as the antioxidant capacity of proteins and other redox-active components in the environment is exceeded (Estevez, 2015). After slaughter, in vivo the antioxidant mechanisms collapse while the biochemical changes that occurred during conversion of muscle to meat favor oxidation (Min \& Ahn, 2005). The $\mathrm{pH}$ decline facilitates the oxidation of the muscle components as $\mathrm{H}^{+}$may promote the redox cycle of myoglobin and its pro-oxidant action. In addition to the $\mathrm{pH}$ decline, other post-mortem biochemical changes, such as changes in the cellular compartmentalization and the release of free-catalytic iron and oxidazing enzymes also contribute to the promotion of LOx (Zhang et al., 2011). The extent of LOx in post-mortem meat is highly dependent on the origin of the meat, type of muscle, species, and storage conditions (Estevez, 2015).

\section{TBARS}

Malondialdehyde (MDA) is a relatively stable secondary product of the oxidative degradation of polyunsaturated fatty acids (PUFAs). It is a three-carbon dialdehyde that can exist in various forms depending on the $\mathrm{pH}$ value. Cyclic peroxides, biclyclic endoperoxides, and hydroperoxyl are some of its major precursors (Lima et al., 2013).
MDA is important for industry and scientific research since it can be used to determine lipid peroxidation through the TBARS test (Thiobarbituric Acid Reactive Substances), the most widely used assay to assess the effects of $\mathrm{LO}$ on meat and meat products (Min \& Ahn, 2005).

\subsection{Factors affecting development of lipid oxidation}

\section{Lipid composition}

Lipids found in biological systems are oxidable in different degrees and consist of one or more of the following classes: mixture of mono-, di- and tri- glycerides, phospholipids, free fatty acids, and sterols. Triglycerides result from the esterification of a molecule of glycerol with three fatty acids and are considered the main responsible for the development of rancidity. The lipid oxidation reactions occur mainly in fatty acids, and the phospholipids present in the membranes and in the subcellular structures can be a good substrate for this reaction (Laguerre et al., 2007; Wójciak \& Dolatowski, 2012).

Lipid oxidation increases significantly with the increase of unsaturated groups (double bond). PUFAs oxidize more rapidly than the monounsaturated fatty acids. The linoleic acid (C18:2) oxidation occurs ten times faster than that of the oleic acid (C18:1), which, in turn, occurs 20 to 30 times slower than that of the oxidation of the linolenic acid (C18:3). This is primarily due to the fact that less energy is required for the removal of hydrogen from a carbon double bond than the energy required to remove it from a methyl carbon, especially when the carbon is between two double-bonds. The hydrogen bonded to this carbon is easily removed and thus lipid peroxidation occurs. In general, the formation of lipid peroxides is not affected by the length of the fatty acid chain, but lipid peroxidation increases exponentially with the number of bis-allylic positions (Lima et al., 2013; Li \& Liu, 2012).

High levels of PUFA in food or diets are generally associated with an increase of concentration of PUFAs in the meat muscles and lipid oxidation in the body. This results in reduced lipid stability and a potential impact on the color stability of the meat, at marginal concentration levels. It was found that when the concentration of linolenic acid (C18: $3 \omega-3)$ is $3 \%$ of the lipids, adverse effects of fatty acids on meat oxidation and flavor occur. A study on muscles of pasture-fed cattle reported the presence of two to three times more PUFAs with three or more double bonds than those of grain-fed cattle. At the same time, there was lower lipid stability, except when there was $\alpha$-tocopherol supplementation or high level of antioxidants in the pasture-fed cattle. Although the high content of PUFA in meat is considered desirable from a nutritional point of view, it can affect the oxidative stability of meat. Dietary antioxidant supplementation is a common way to solve this problem ( $\mathrm{Li} \& \mathrm{Liu}, 2012$ ).

\section{Metal ions}

Lipid oxidation in meat can be triggered by metal ions that can easily donate electrons, such as copper and iron, leading to increased rate of free radical production (Lima et al., 2013). 
Iron

Iron is the most abundant transition metal in biological systems and has multiple oxidation state, reduction potential, and electron configuration. There is extensive evidence that this metal has an important role in lipid peroxidation as a primary initiator and catalyst. Iron can catalyze the production of hydroxyl radical $(\bullet \mathrm{OH})$ via the Fenton reaction (E4) (Min \& Ahn, 2005; Min et al., 2010):

$$
\text { Complex }-\mathrm{Fe}(\mathrm{II})+\mathrm{H}_{2} \mathrm{O}_{2} \cdot \rightarrow \text { Complex }-\mathrm{Fe}(\mathrm{III})+\mathrm{OH}-+\cdot \boldsymbol{O H}
$$

Furthermore, the ferrylmyoglobin formed by the interaction between $\mathrm{H}_{2} \mathrm{O}_{2}$ and metmyoglobin can abstract a hydrogen atom from a bis-allylic position of a PUFA and initiate lipid peroxidation (Min et al., 2010).

Iron is found in five different pools in biological systems: transferrin, ferritin, heme pigments, iron-dependent enzymes, and small iron chelates (also called "free iron"). It has been suggested that free iron and/or ferrylmyoglobin are primarily responsible for lipid peroxidation in meat (Min et al., 2010).

\section{Myoglobin}

It is known that the muscles with higher concentration of myoglobin are more susceptible to lipid oxidation (Lima et al., 2013). There is evidence that the interaction of metmyoglobin with hydrogen peroxide or lipid hydroperoxides (LOOH) results in the formation of ferrylmyoglobin, which can initiate the free radical chain reaction. Furthermore, ferrylmyoglobin as well as metmyoglobin can degrade $\mathrm{LOOH}$ to free radicals such as peroxyl and alkoxyl radicals, which can initiate or catalyze a series of propagation and termination steps of LOx. Some authors limited the role of myoglobin as only a source of free ionic iron or hematin, indicating that the free iron and/or hematin released from myoglobin in the presence of $\mathrm{H}_{2} \mathrm{O}_{2}$ and lipid hydroperoxide, rather than ferrylmyoglobin, may be major catalysts of LOx. A more recent study suggested that lipid peroxidation induced metmyoglobin can be caused by ferrylmyoglobin or by the hematin generated in interaction between metmyoglobin and $\mathrm{LOOH}$, rather than the released iron (Min et al., 2010; Min et al., 2008).

\section{Ferric Reducing Aantioxidant Power (FRAP)}

The ability of antioxidant compounds to reduce the ferric ion to ferrous ion has been used to evaluate the antioxidant activity in meat. Several antioxidant compounds, such as ascorbic acid, NADPH, and thiol compounds (glutathione), are present in biological cells and are probably responsible for the ferric reduction capacity in meat. Ascorbic acid is an important biological reducing agent capable of serving as an electron donor in oxidative processes mediated by free radicals. Ascorbic acid may serve both as an antioxidant and as a pro-oxidant, depending on its concentration. It has been suggested that ascorbic acid in low concentrations tends to promote lipid peroxidation in muscle tissues by reducing ionic iron, whereas at high concentrations, it tends to inhibit LOx by regenerating antioxidants such as $\alpha$-tocopherol in the cell membrane. The effect of the concentration of ascorbic acid on lipid peroxidation also depends on the iron concentration (Min et al., 2010, 2008).

\section{Lipoxygenase}

Lipoxygenase is an enzyme essential for the eicosanoid biosynthesis from the arachidonic acid in cell membranes, and it is present in the muscle tissue of various mammals. This enzyme can directly oxygenate PUFAs forming lipid hydroperoxides. Thus, lipoxygenase may be involved in the initiation of lipid peroxidation in meats (Min et al., 2008).

\section{Lipid oxidation in different animal species}

The susceptibility of meat to lipid peroxidation depends on the animal species, type of muscle, and anatomical location according to the presence and/or composition of the factors (Min \& Ahn, 2005).

Raw beef is much more susceptible to LOx than raw pork and raw chicken (Min et al., 2008). This difference is mainly due to the considerably larger amount of iron and myoglobin in bovine muscle (Min et al., 2008; Estevez, 2015).

On the other hand, chicken meat proved to be more susceptible to LOx than pork and beef meat when exposed to intense pro-oxidant environments such as that created during heat treatment (Min \& Ahn, 2005). Min et al. (2008) found similar TBARS levels in cooked beef and chicken drumsticks (internal temperature of $75^{\circ} \mathrm{C}$ ), which were considerably higher than the levels found in pork and cooked chicken breast.

These findings indicate that the content of free ionic iron and myoglobin and the ferric reducing ability were the main determinants for the differences in susceptibility of raw meats to LOx. On the other hand, for cooked meats (under heating), the main determinants seem to be free ionic iron content, heat-stable ferric iron reducing capacity, and PUFA levels, when there is sufficient amount of free iron (Min et al., 2008).

\section{Storage and processing conditions}

Several factors involved in processing and storage, such as size reduction processes, heating, maturation, boning, additives, oxygen exposure, temperature, and storage time, can influence the rate of LOx in meat and meat products. Oxygen exposure is one of the most important factors for the development of LOx. Therefore, any process that leads to membrane rupture (exposing phospholipids to oxygen) and/or size reduction (increased contact surface), such as cutting, grinding, boning, and cooking can accelerate the development of oxidative rancidity. Oxygen exposure is also an essential factor contributing to LOx during storage. It has been shown that in the absence of oxygen, pro-oxidants exert minimal effects on oxidation during storage. Furthermore, some authors reported that TBARS values of vacuum packaged meat immediately after cooking (still warm) were significantly lower during storage than those of meat packaged after cooling, indicating that this "rest" time (3 hours) was sufficient to stimulate lipid peroxidation in cooked meat (Min \& Ahn, 2005). 
In addition to exposing the phospholipids to oxygen, cooking also promotes the release of nonheme iron from heme pigments. Slow heating was shown to increase the release of non-heme iron more rapidly than fast heating. Also, high temperatures provide reduced activation energy for oxidation and break down of hydroperoxide into free radicals. On the other hand, it has also been shown that freezing slows down lipid peroxidation and retards the development of $\mathrm{NADH}$-dependent lipid peroxidation by inactivating the enzymes, but thawing results in reactivation of the peroxidase system. $\mathrm{LOO} \bullet$ is soluble in oil fraction and is more stable at low temperatures; thus, it can diffuse to longer distances and spread the reaction potential during freezing (Min \& Ahn, 2005).

\section{$\mathrm{NaCL}$}

Sodium chloride is one of the most important additives in meat industry, where it is used for enhancing preservation, flavor, softness, and water retention capacity among others. However, it is known that it has a pro-oxidant effect in meats and meat products, depending on its concentration. It has been reported that sodium chloride increases the level of lipid oxidation when in concentrations of up to $2 \%$ but over $3 \%$ of sodium chloride showed little or no pro-oxidant effect. The mechanism by which sodium chloride promotes lipid oxidation has not yet been clearly understood, but one possible explanation is that $\mathrm{NaCI}$ may disrupt the structural integrity of the membrane enabling catalysts to have access to substrates. Some authors suggest that $\mathrm{NaCl}$ could increase the activity of ionic iron for LO (Min \& Ahn, 2005); Rhee \& Ziprin (2001) reported the ability of this salt to release ionic iron from iron-containing molecules such as heme proteins and found that it can promote the formation of metmyoglobin. Another suggested mechanism is the sodium chloride ability to decrease the activity of antioxidant enzymes, such as catalase, glutathione peroxidase, and superoxide dismutase (Min \& Ahn, 2005).

\subsection{Protective factors}

\section{Supplementation and diet}

It is known that the presence of exogenous antioxidants in the animal diet can increase the stability of lipid of meat ( $\mathrm{Li} \&$ Liu, 2012). These antioxidants can reduce the impact of some sources of oxidative stress (heating) and thereby inhibit their adverse effect on the muscle tissue (Ismail et al., 2013).

In general, dietary strategies to reduce the effects of lipid oxidation on meat involve changes in the lipid composition of the feeds and antioxidant supplementation. Supplementation with a-tocopherol is the most commonly used (around $200 \mathrm{mg} / \mathrm{kg}$ feed) alone or in combination with ascorbate (up to $1000 \mathrm{mg} / \mathrm{kg}$ feed), phenolic compounds, or other elements with antioxidant potential, such as selenium, magnesium, zinc (Estevez, 2015).

\section{Type of diet and lipid composition (ruminants)}

The animal feeding system (grass, grain, or mixed) can affect the lipid composition and concentration of vitamin $\mathrm{E}$ in the animal muscles (Bekhit et al., 2013).
Generally, grass-fed cattle have higher level of long-chain omega-3 and conjugated linoleic acid (CLA) fatty acids than grain-fed cattle (Daley et al., 2010).

Despite the higher concentration of fatty acids susceptible to lipid oxidation (PUFAs and CLAs) found in grass-fed cattle, the rate of lipid peroxidation in the meat of these animals was lower. This is due to the fact that grass-based-diets are rich in $\alpha$-tocopherol and $\beta$-carotene, which exert a protective effect on fatty acids (Descalzo \& Sancho, 2008; Daley et al., 2010). Higher antioxidant enzyme activity has also been reported in animals fed this type of diet (Bekhit et al., 2013).

Some dietary strategies, such as the addition of $7 \%$ of fish in the feed, can result high levels of PUFAs in meat without compromising oxidative stability of lipids (Bekhit et al., 2013).

\section{Alpha-Tocopherol}

Alpha-tocopherol is the most commonly used antioxidant in diets of monogastric and ruminant animals. This dietary supplementation results in high concentrations of $\alpha$-tocopherol in the cellular membranes, which neutralizes free radicals generated during processing and during postmortem storage (Li \& Liu, 2012).

Liu et al. (2011) found that $a$-tocopherol accounted for $79 \%$ of the variation in lipid stability (TBARS) and that the optimal $\alpha$-tocopherol concentrations for antioxidant capacity was $3-3.5 \mathrm{mg} / \mathrm{kg}$ of tissue. Higher $\alpha$-tocopherol concentrations did not affect antioxidant capacity.

The level of $a$-tocopherol in the muscle before supplementation should be taken into account since the muscles of grass-fed cattle have, in general, high concentrations of this antioxidant; therefore, dietary supplementation will not be very effective (Li \& Liu, 2012).

Descalzo \& Sancho (2008) indicated that grass-based-diets provide a significantly higher concentration of a-tocopherol than grain-based-diets. Therefore, the literature suggests that grass-based-diets considerably improve the lipid stability of meat, when there is high concentration of vitamin E (Li \& Liu, 2012).

\section{Minerals}

Selenium is the main antioxidant used as a dietary supplement to control lipid oxidation in meats. It is an integral component of glutathione peroxidase, an enzyme that along with vitamin $\mathrm{E}$ is responsible for cellular defense against free radicals (Liu et al., 2011; Habibian et al., 2016)

Habibian et al. (2016) reported that selenium supplementation ( 0.5 and $1 \mathrm{mg} / \mathrm{kg}$ ) can improve lipid stability in broiler chickens under thermal stress. Some studies suggest that selenium yeast may be a promising dietary strategy to improve the oxidative stability of poultry meat (Ahmad et al., 2012; Surai \& Fisinin, 2014). Delles et al. (2014) have recently reported that supplementation with selenium yeast enhances the oxidative stability of lipids and proteins of chicken broiler meat through promotion of antioxidant enzyme activity. 
Zinc is also a component of an antioxidant enzyme, the superoxide dismutase. Accordingly, Tres et al. (2010) evaluated the effect of zinc supplementation on lipid stability of rabbit meat. The authors found a slight decrease in susceptibility to lipid oxidation in the meat of rabbits fed rich PSO (peroxidized sunflower oil) diet and a slight increase in susceptibility to lipid oxidation in rabbits fed diets rich in OSO (oxidized sunflower oil).

Other trace elements such as copper and nickel at doses higher than 200 and $300 \mathrm{mg} / \mathrm{kg}$, respectively, have pro-oxidant effect on chicken meat (Wu et al., 2013).

\section{Phenolic compounds}

Phenolic metabolites are common components of fruits and vegetables and have high antioxidant activity. The antioxidant properties of phenolic acids and flavonoids depend on their redox properties and chemical structure, which allow them to act as reducing agents, hydrogen donors, and singlet oxygen quenchers. Additionally, some compounds have chelating activity, which prevents transition metals to act as oxidation promoters (Kumar et al., 2015).

Dietary strategies based on vegetable products rich in phenolic compounds have been shown to be effective against lipid and protein oxidation. Among them are thymol, tannic acid, and gallic acid (Starčević et al., 2015), ginger root (Zingiber officinale) (Zhao et al., 2011), rose hips (Rosa canina) and rosemary leaves (Rosmarinus officinalis) (Loetscher et al., 2013), and pomegranate by-products (Punica granatum) (Ahmed et al., 2015; Emami et al., 2015). In addition to the inhibition of oxidative stress, some herbs and their essential oils can contribute positively to the performance, digestibility, and gut microflora of animals (Cross et al., 2007). Supported by promising results, the use of phytogenic additives has recently been proposed as an alternative to antibiotics to control oxidative stress in broiler chickens. Table 1 summarizes some recent studies on the effect of supplementation with phenolic compounds on oxidative stability.

Table 1. Effect of supplementation with phenolic compounds on oxidative stability.

\begin{tabular}{|c|c|c|c|}
\hline Antioxidants & Product & Results & Reference \\
\hline $\begin{array}{l}\text { Rosemary (Rosmarinus officinalis), rose } \\
\text { hips (Rosa canina), chokeberrey (Aronia } \\
\text { melanocarpa), and common nettle (Urtica } \\
\text { dioica), compared to vitamin E }\end{array}$ & $\begin{array}{c}\text { Chicken breast } \\
\text { (Gallus gallus domesticus) }\end{array}$ & $\begin{array}{l}\text { Among the dietary antioxidants investigated, } \\
\text { rosemary proved to be the most adequate, despite } \\
\text { having low concentration of vitamin E. Rose hip } \\
\text { and Aronia also showed interesting properties. }\end{array}$ & $\begin{array}{l}\text { Loetscher et al. } \\
\text { (2013) }\end{array}$ \\
\hline
\end{tabular}

Thymol, tannic acid, and gallic acid

Ginger (Zingiber officinale) powder at $5 \mathrm{~g} / \mathrm{kg}$, $10 \mathrm{~g} / \mathrm{kg}, 15 \mathrm{~g} / \mathrm{kg}$, and $20 \mathrm{~g} / \mathrm{kg}$

Suplemmentation with extracts of $\alpha$-tocoferil acetate, $\boldsymbol{\alpha}$-tocoferol, rosemary (Rosmarinus officinalis), green tea (Camellia sinensis), grape seed (vitis spp), and tomato (Solanum lycopersicum).

Suplemmentation with pomegranate

(Punica granatum) seed pulp (PSP)

1 - Control

2 - $5 \%$ PSP

3 - $10 \%$ PSP

$4-15 \%$ PSP

Suplemmentation with by-products of pomegranate (Punica granatum)

$(0,0.5,1.0$, and $2.0 \%)$

Comparison between free-range pigs and fed diets supplemented with extracts: $200 \mathrm{mg} / \mathrm{kg}$ of synthetic $\alpha$-tocoferil acetate, $200 \mathrm{mg} / \mathrm{kg}$ of natural $\alpha$-tocoferil acetate, $200 \mathrm{mg} / \mathrm{kg}$ of extract rich in flavonoids, and $200 \mathrm{mg} / \mathrm{kg}$ of extract rich in phenolic compounds.

Supplementation with phenolic diterpenes from rosemary (arnosic acid and carnosol) compared to vitamin $\mathrm{E}$.
Chicken thigh and breast (Gallus gallus domesticus)

Broiler chickens (Gallus gallus domesticus) (plasma)

Young broiler chickens

(Gallus gallus domesticus) (plasma)

Goat meat

(Capra spp. - Longissimus lumborum)

Young broiler chickens

(Gallus gallus domesticus)

Iberian pig muscle

(Sus scrofa mediterraneuslongissimus dorsi.)

Lamb meat

(Ovis aries -Longissimus thoracis et lumborum)
The tannic and gallic acids significantly reduced TBARS values in broiler breast meat, as compared to the control.

The results indicate that the optimal concentration of ginger powder to improve the lipid stability was $10-15 \mathrm{~g} / \mathrm{kg}$.

Plasma oxidative state and lipid oxidation in young broiler chickens were not affected by supplementation with different natural antioxidants. However, some changes (increase) in the antioxidant enzyme activity were observed.

The oxidative stability of raw and cooked meat can be improved with a diet containing 15\% PSP.

Starčević et al. (2015)

Zhao et al.

Vossen et al.

Emami et al. (2015)

Supplementation with pomegranate byproducts, especially $1.0-2.0 \%$ significantly reduced lipid oxidation.

Pigs fed natural a-tocopheril showed similar results to those of pigs free-range pigs, with lower lipid oxidation. Pigs fed extracts rich in flavonoids and phenolics showed results similar to those of the control, with no significant influence on lipid oxidation.

Supplementation with phenolic diterpenes from rosemary or a-tocopherol were effective in preventing lipid oxidation, but supplementation with $a$-tocopherol proved to be the most adequate strategy to extend the shelf life of the lamb. 
Ractopamine is a $\beta$-adrenergic agonist that affects animal metabolism inhibiting lipogenesis stimulating lipolysis and nitrogen retention, leading to an increase in protein synthesis. Studies suggest that in addition to increasing lean mass, ractopamine also contributes to the reduction of lipid oxidation in pork meat (Leal et al., 2014; Silva et al., 2015).

Although it is a common practice in Brazil and in other countries such as the U.S., supplementation with ractopamine has been banned in many other countries (China, Russia, and the European Union). There are no conclusive studies concerning the long term effects of this compound. The MAPA - Ministério da Agricultura, Pecuária e Abastecimento (Ministry of Agriculture, Livestock and Supply) has established the maximum residue limit of $20 \mu \mathrm{g} / \mathrm{kg}$ in pork and poultry muscle and $5 \mu \mathrm{g} / \mathrm{kg}$ in beef muscle. According to this regulatory agency, ractopamine is allowed to be used only in feed of pigs in termination phase as a nutrient divider at the concentration of 5-20 g/ton of feed (Universidade Federal do Rio de Janeiro, 2013).

\section{Antioxidant additives}

Antioxidants are compounds capable of donating hydrogen radicals $(\mathrm{H} \bullet)$ to free radicals available to prevent oxidative damage (Srinvasan et al., 2008).

$$
A: H+R O \bullet \rightarrow A \cdot+R O H
$$

This retards lipid oxidation and rancidity without damage to sensory and nutritional properties, which maintains quality and extend shelf life of meat and meat products. Although there are intrinsic factors in live muscles to prevent lipid oxidation, they are often lost after slaughtering, during muscle conversion of muscle to meat, primary and secondary processing, handling and storage; therefore, supplementation with extrinsic antioxidants is necessary.

For this reason, synthetic antioxidants, such as BHT and BHA, have been widely used to delay or prevent lipid oxidation by scavenging chain-carrying peroxyl radicals or suppressing the formation of free radicals. However, because of the concern over the safety of these synthetic compounds, the use of natural antioxidants in meat has been widely studied. Natural antioxidants have great application potential in the meat industry. It is known that plant extracts, herbs, spices, and essential oils have significant antioxidant capacity, but their application in the industry is still limited due to the lack of sufficient data about their efficiency and safety in different amounts and products (Kumar et al., 2015).

\section{Synthetic Antioxidants}

BHA, BHT, and TBHQ are examples of synthetic chain breaking antioxidants. They are aromatic rings that can donate one $\mathrm{H} \bullet$ to an oxidizing lipid. This stops the oxidation process by forming a more stable compound. The propyl gallate (PG) is an aromatic antioxidant with three-OH groups on the phenol ring, capable of donating $\mathrm{H} \bullet$. On the other hand, ethylenediamine tetra acetic acid (EDTA) is a metal chelator which binds iron preventing catalyzed oxidation of this metal. The concentration of synthetic antioxidants allowed in food is limited to $0.01 \%$ of fat content (when used individually). Nowadays, the acceptability of synthetic additives by consumers is low since certain toxicity and carcinogenicity have been identified in some studies (Faine et al., 2006). For these reasons, the interest of the meat industry in using natural antioxidants has increased considerably (Kumar et al., 2015).

\section{Natural antioxidants}

Natural antioxidants are an interesting alternative to conventional antioxidants. Although, they are generally more expensive and less efficient, these components are better accepted by consumers and are considered safer. Moreover, some natural compounds have higher antioxidant capacity than synthetic compounds and some also have other positive effects on the sensory properties of meat products (Kumar et al., 2015; Velasco \& Williams, 2011).

Natural antioxidants include various substances with different chemical characteristics, which can be found in any plant part such as grains, fruits, kernels, seeds, leaves, roots, peels, and barks. The antioxidant capacity of natural extracts is related to the presence of compounds such as vitamins $\mathrm{A}, \mathrm{C}$ and $\mathrm{E}$, flavonoids, and other phenolic compounds. The majority of natural antioxidants found in nature are phenolic compounds, among which are tocopherols, flavonoids, and phenolic acids. These compounds have strong $\mathrm{H} \bullet$-donating activity or have high radicals-absorbance capacity (Kumar et al., 2015; Velasco \& Williams, 2011; Ding et al., 2015). Some phenolics prevent free radical generation and the formation of reactive oxygen species, while others scavenge free radicals and chelate pro-oxidants (transition metal). The antioxidant potential of these natural compounds (phenolics) depends on their structure and distribution of functional groups in these structures. For example, the number and position of free hydroxyl groups $(-\mathrm{OH})$ in the structure of a flavonoid determines its free radical- scavenging potential. The presence of multiple-OH groups and ortho-3,4dihydroxy structures enhance the antioxidant potential of plant-based phenolic compounds. Polymeric structures (containing more-OH groups) have greater antioxidant potential, whereas glycolsylation of functional groups (reduction of - $\mathrm{OH}$ ) decreases antioxidant potential (Kumar et al., 2015). The most important sources of natural antioxidants used in the industry will be discussed individually below.

Ascorbic acid

Ascorbic acid (AA) is a chelating agent that binds metal ions; it also scavenges free radicals and act as a reducing agent. At high levels (>100 mg/kg), AA inhibits oxidation; however, at low levels $(<100 \mathrm{mg} / \mathrm{kg})$, it can catalyze oxidation and contribute to the development of off-flavors. It is commonly used in combination with other antioxidants, especially tocopherols (Ismail et al., 2013)

\section{Carotenoids}

Carotenoid compounds are widely used as natural pigments and also have antioxidant properties (Domenech-Asensi et al., 2013). They can act as singlet oxygen (E1) quenchers, react with free radicals (E2), or act as chain-breaking agents under specific 
conditions (Mercadante et al., 2010). Some studies have reported that carotenoids such as norbixin, lycopene, zeaxanthin, and $\beta$-carotene have good antioxidant activity in food (Boon et al., 2009; Kiokias et al., 2009; Mercadante et al., 2010). However, it is important to mention that in addition to acting as antioxidants, carotenoids can act as pro-oxidants (E3), depending on various factors including storage conditions, concentration, carotenoid type, the presence of other antioxidants and pro-oxidants at high oxygen pressures (Boon et al., 2009). It is known that the carotenoid structure has great influence on their antioxidant activity, which enhances according to the number of conjugated double bonds, ketogroups, and the presence of cyclopentane rings. For example, cataxantina and astaxanthin have better antioxidant activity than that of $\beta$-carotene or zeaxanthin (Uenojo et al., 2007).

$$
\begin{aligned}
& { }^{1} O 2+C A R \rightarrow{ }^{3} O 2+{ }^{*} C A R \\
& R \cdot+C A R(H) \rightarrow R H+{ }^{*} C A R \\
& { }^{*} C A R+O 2 \rightarrow R O 2 \cdot
\end{aligned}
$$

${ }^{\star} \mathrm{CAR}=$ excited state carotenoid; it can easily return to the ground state, dissipating the energy as heat.

\section{Tocopherols}

Tocopherols are effective natural fat-soluble antioxidants; a-tocopherol can serve as a chain breaker and electron donor by competing with the substrate over peroxyl radicals. Furthermore, the antioxidant activity of $\alpha$-tocopherol can also be associated with retarding the decomposition of hydroperoxides (Georgantelis et al., 2007). It has been reported that $\alpha$-tocopherol is commonly used in animal feed to increase the oxidative stability of meat. Some studies on the postmortem supplementation of vitamin $\mathrm{E}$ as an additive suggest that it is less effective in retarding lipid oxidation than dietary supplementation (Velasco \& Williams, 2011).

\section{Herbs (Lamiaceae)}

Studies on herbs of the Lamiaceae family, especially oregano (Origanum vulgare L.), rosemary (Rosmarinus officinalis L.), sage (Salvia officinalis L.), and thyme (Thymus vulgaris L.) have shown their significant antioxidant capacity, primarily due to phenolic -OH groups. Herbs with high levels of phenolic compounds, such as phenolic acids (e.g. gallic, caffeic, and rosamarinico acids) have strong $\mathrm{H}$-donating acitivity and are effective scavengers of $\mathrm{H}_{2} \mathrm{O}_{2}$ and superoxide radicals (Velasco \& Williams, 2011).

Rosemary can inhibit lipid oxidation, chelate metal and eliminate superoxide radicals. Its phenolic content corresponds to about $150 \mathrm{mg} / \mathrm{g}$. The substances responsible for the antioxidant activity include phenolic acids (caffeic, ferulic, and rosamarinic acid) and phenolic diterpenes (carnosic acid and carnosol). Carnosic acid and carnosol act as iron chelators and eliminate peroxyl radicals, especially in lipophilic systems. Despite the beneficial effects, some of the compounds found in rosemary (verbenone, borneol, camphor) can impart an undesirable odor to food, even at low concentrations (Velasco \& Williams, 2011).

Oregano has been reported as the laminaceae herb with the highest antioxidant activity (Munchweti et al., 2007).
The compounds responsible for antioxidant activity of oregano include caffeic, coumaric and rosamarinic acids, carvacrol, thymol, and flavonoids. Sage contains a variety of antioxidants such as carnosol, rosmanol, rosamadiol, isorosmanol, galdosol and carnosic acid. Its antioxidant activity is related to oxygenated diterpene of oxygen and sesquiterpene concentration. The essential oils of sage can reduce the lipid oxidation in meat; however, this effect is more pronounced when used in cooked meat than in raw meat (Fasseas et al., 2008). Finally, thyme contains several antioxidant compounds, which when isolated have the following order of antioxidant activity: thyme oil $>$ thymol $>$ carvacrol $>$ gamma-terpinene $>$ myrcene $>$ linalool $>$ p-cymene $>$ limonene $>$ 1,8-cineolo > alpha-pinene (Rojas \& Brewer, 2008).

\section{Spices (Lauraceae)}

The antioxidant and antimicrobial capacities of spices have been extensively studied. Clove (Syzygium aromaticum), cinnamon (Cinnamomum zeylanicum), nutmeg (fragrans Myristica), and black pepper (Piper nigrum) are examples of commonly used spices with antioxidant activity, mainly due to the presence of phenolic compounds such as coumaric, ferulic, and gallic acids, volatile oils, and flavonoids. Spices and herbs have similar chemical composition and roles (Radha et al., 2014).

\section{Green tea and grape seed}

Green tea (Camellia sinensis) has high antioxidant activity due to the presence of flavonoids, tannins, and vitamins. The antioxidant activity of green tea infusions is mainly attributed to its phenolic content. Its phenolic compounds include catechins and polyphenolic flavonoids, which are particularly effective in eliminating free radicals (Kim et al., 2013a).

Grape seed extracts (Vitis spp.) are also sources of phenolic compounds such as caffeic acid, proanthocyanidins, resveratrol, and catechins. The compounds with the highest antioxidant activity in grape seed are gallic acid and epigallocatechin, which have phenols with three-OH groups bonded to the aromatic ring adjacent to each other. Grape seed extract has been shown to be effective in reducing lipid oxidation in both raw and cooked meat and minimizing WOF (Rojas \& Brewer, 2008).

In addition to the aforementioned antioxidant sources, many others have been explored to reduce lipid oxidation and increase shelf life of meat and meat products. Some examples are extracts of pomegranate, acerola, lychee, and jabuticaba (Plinia jaboticaba). Table 2 summarizes some recent studies addressing the effect of natural antioxidants on oxidative stability of meat and meat products.

\subsection{Packaging}

Modern meat and meat product-packaging methods offer benefits beyond conventional protection properties to meat and meat products. Vacuum, modified atmosphere, and active packaging are techniques that have extended shelf life of these products (Pereira et al., 2015). Considering that oxygen is the most common and essential component for the progress of lipid oxidation, packaging that reduce or limits oxygen exposure is a good strategy to prevent and retard LOx (Xiao et al., 2011). 
Table 2. Effect of natural antioxidants on oxidative stability of meat and meat products.

$\frac{\text { Antioxidant }}{\text { Extracts of Thuja occidentalis and peach }}$ seeds (Prunus armeniaca)

Extracts of Clove (Syzygium aromaticum), cinnamon (Cinnmomum cassia), oregano (Origanum vulgare), and balck mustard (Brassica nigra)

Oregano (Origanum vulgare), sage (Salvia officinalis), and honey

Fermented rooibos (Apalathus linearis) $(0 \%, 0.25 \%, 0.5 \%$, and $1 \%)$ and unfermented rooibos (2\%)

Extracts of green tea (Camellia sinensis) and grape seed (Vitis spp.) compared to sodium ascorbate

Conventional and supercritical extracts of Echinacea angustifolia

Extracts of green leafy vegetables: Petasites (Petasites japonicus Maxim), chamnamul (Pimpinella brachycarpa (Kom.) Nakai), bok choy (Brassica campestris L. ssp. chinensis), nira (Allium tuberosum Rottler ex Spreng), Chrysanthemum coronarium L., fatsia (Aralia elata Seem), pumpkin (Curcubita moschata Duch.), Perilla frutescens var. japonica Hara, sedum (Sedum sarmentosum Bunge), and brocolis (Brassia oleracea L. var. italica Plenk)

Extract of blackcurrant (Ribes nigrum L.)

Rice protein hydrolysates

Dehidrated vegetable powder: beet (Beta vulgaris), brocolis (Brassica oleracea), carrot (Daucus carota), celery (Apium graveolens), green peas (Pisum ivum), onion (Allium cepa), red pepper (Capsicum annuum), spinach (Spinacia oleracea), yellow turnip, Brassica napobrassica, and tomato (Solanum lycopersicum)
Raw broiler meat (Gallus gallus

domesticus)

Roasted broiler meat (Gallus gallus domesticus)

Salami and ostritch burger (Struthio camelus)

\section{Cooked pork meatballs \\ (Sus domesticus)}

Cooked broiler meatballs (Gallus gallus domesticus)

Beef hamburger (Bos taurus)

Raw pork burger (Sus domesticus)

Cooked ground beef (Bos taurus)

Fried turkey burger (Meleagris spp.)
Both extracts inhibited lipid peroxidation by MDA formation, and increased water retention capacity. However, some of these sources also have antinutritional factors and some potentially toxic compounds if consumed in large amounts. It would be necessary to isolate and characterize the components that contribute to antioxidant activity.

The clove extract showed higher antioxidant activity, individually. The combined extracts were quite effective against lipid oxidation, suggesting a synergistic effect between these compounds.

The results confirmed the antioxidant effects of the ingredients used when added before processing. The method increased shelf life and improved oxidative stability of meat after $96 \mathrm{~h}$ of refrigeration at $4{ }^{\circ} \mathrm{C}$.

The study showed promising results terms of antioxidant potential of rooibos (red tea) in meat products. When added at concentrations starting from $0.5 \%$, rooibos decreased lipid oxidation and increased shelf life of the products.

The natural antioxidant was more effective than sodium ascorbate in retarding lipid oxidation. The sensory attributes on day 0 were not affected by presence of natural antioxidants.

The two extracts were effective in protecting the broiler meat against lipid oxidation; however, the supercritical extract was more selective. Despite the positive effects on lipid stability, these extracts have a strong flavor, which can affect the organoleptic properties of the product.

All extracts showed some protective effect against lipid oxidation, but the extracts of chamnamul and fatsia showed higher antioxidant activity than the others. Despite the positive effects, these extracts contain natural green pigments that negatively impact the color of meat.

Blackcurrant extract proved to be a powerful antioxidant in pork burger inhibiting lipid and protein oxidation maintaining the red color during cold storage.

Some hydrolysates had little inhibitory effect on lipid oxidation.

Of the eleven vegetable powders used, six post significantly improved the oxidative stability of the burgers by $20 \%-30 \%$, in the following order: spinach $<$ yellow turnip $<$ onion $<$ red pepper $<$ green peas $<$ tomato
Radha et al. (2014)

Sampaio et al.

Cullere et al. (2013)

Price et al. 2013

Gallo et al. (2012)

Kim et al. (2013a)

Jia et al. (2012)

Zhou et al. (2011)

Duthie et al. (2013) 
Table 2. Continued...

\begin{tabular}{|c|c|c|}
\hline Antioxidant & Product & Result \\
\hline Pomegranate juice (Punica granatum) & $\begin{array}{l}\text { Broiler breast (Gallus } \\
\text { gallus domesticus) }\end{array}$ & $\begin{array}{l}\text { The natural antioxidant reduced lipid and protein } \\
\text { oxidation, and the samples were sensorially acceptable } \\
\text { up to day } 12 \text { under cold storage at } 4^{\circ} \mathrm{C} \text {. }\end{array}$ \\
\hline $\begin{array}{l}\text { Lychee (Litchi chinensis Sonn) at } 0.5 \%, 1.0 \% \text {, } \\
\text { and } 1.5 \%\end{array}$ & $\begin{array}{l}\text { Emulsified pork } \\
\text { meatballs } \\
\text { (Sus domesticus) }\end{array}$ & $\begin{array}{l}\text { Although the lychee intensified the red color of } \\
\text { meatballs turning them darker than the control } \\
\text { group, it did not affect the preference of the panelists. } \\
\text { The addition of } 0.5 \% \text { of lychee powder obtained the } \\
\text { highest sensory acceptance. The study suggests that } \\
\text { lychee can be an effective antioxidant to reduce lipid } \\
\text { and protein oxidation in cooked and frozen meat } \\
\text { products. }\end{array}$ \\
\hline
\end{tabular}

Traditional Mexican spices: soft paste, urucum (Bixa orellana) and pasilla peppers (Capsicum annuum)

Extract of jabuiticaba peel (Plinia jaboticaba)

Tomate paste (Solanum lycopersicum)

Extract of acerola (Malpighia emarginata) $(0.15 \%)$

Extract of rosemary (Rosmarinus officinalis)

Extracts de marjoran (Origanum majorana), Rosemary (Rosmarinus officinalis), and sage (Salvia officinalis) (0.04\%)

Extracts of wine industry residues: Niagara and Isabel grape seeds and peel.

Chitosan / 4\% fructose
Pork meat (Sus domesticus)

Mortadella

Mortadella

Beef hamburger

(Bos taurus)

Turkey meatballs

(Meleagris spp.)

Irradiated ground beef (Bos taurus)

Frozen raw and cooked broiler meat (Gallus gallus domesticus)
Pasilla peppers showed higher antioxidant activity, than that of the soft paste and urucum, probably due to the degradation of active compounds during processing.

The jabuticaba peel extract at $0.5 \%, 0.75 \%$, and $1.0 \%$ showed high antioxidant power.

Tomato paste increased product stability and shelf life by significantly reducing lipid oxidation associated with storage.

Addition of acerola extract extended shelf life by at least 3 days improving color and lipid stability and decreasing rancid flavor.

The antioxidant retarded lipid oxidation and hydrolysis and improved color stability.

The addition of herbal extracts minimized lipid oxidation and off-odor and improved product color.

The study suggests that extracts of these two grapes are effective in retarding lipid oxidation in raw and cooked broiler during frozen storage.

The effect of chitosan/fructose Maillard reaction products (CF-MRPs) as antioxidant and antimicrobial agents was evaluated as effective when applied on minced beef meat during frozen storage.
Reference

Vaithiyanathan et al. (2011)

Zhou et al. (2011)

Alvarez-

Parrilla et al. (2014)

Almeida et al. (2015)

DomenechAsensi et al. (2013)

Realini et al. (2015)

Karpińska-

Tymoszczyk (2014)

Mohamed et al. (2011)

Selani et al. (2011)

Shaheen et al. (2016)
Vacuum packaged meat refers to meat placed in a plastic film package with low permeability to oxygen, in which air is removed prior to sealing. During vacuum application, the package shrinks ensuring tight contact to the meat. When the meat is packaged in low-permeability films leaving little space for the accumulation of any fluid exudate, the residual $\mathrm{O}_{2}$ remaining in the package will be quickly converted to carbon dioxide by the respiratory activity of the meat (Mills et al., 2014). Due to its cost-effectiveness and ease of application, vacuum packaging has been the most widely used technique for meat packaging. However, this method has some disadvantages such as deformation of the product and exudate forming. In view of this, modified atmosphere packaging has become a commonly used technique for packaging of meat and meat products (Pereira et al., 2015).

Modified atmosphere is a technique that allows modifying the gas composition within the package according to the optimum conditions for the preservation of each product. In the case of red meat, for example, $\mathrm{CO}_{2}$ is used to extend shelf life due to its antimicrobial properties. An environment with predominance of $\mathrm{CO}_{2}$ is very effective in preventing lipid oxidation; however, the excess of carbon dioxide imparts a sour taste to the meat, which can be reduced by allowing a 30 minute-rest after opening the package. $\mathrm{N}_{2}$, an inert gas, is used to add volume and preserve the product integrity, while $\mathrm{O}_{2}$, although accelerating lipid oxidation, is used to maintain the red color, which influences consumer acceptance. In order to prevent the development of off-flavors due to oxidation, when $\mathrm{O}_{2}$ is required it should be restricted to the minimum necessary (O'Sullivan et al., 2015).

Active packaging is a relatively novel technology designed to incorporate components in the packaging that can absorb or release substances into or from the packaged food or the environment surrounding the food to extend shelf life and maintain or improve the condition of packaged food. This technology offers several advantages compared to the direct addition, such 
as lower amounts of active substance required, migration from film to the food matrix (which may be used to maintain the antioxidant effect for longer protection), and elimination of additional processes. Research on active packaging of meat has focused more on antimicrobial substances; however there has been growing interest in the use of antioxidants in packaging, and recent studies have shown promising results (Bolumar et al., 2011).
Active packaging with antioxidants includes variety of technology approaches. Most of them consist of the direct addition of the antioxidant to the plastic materials or the co-extrusion of antioxidant with the plastic film. Another effective approach is to use film coatings containing antioxidants extracts (Camo et al., 2011).

Table 3 summarizes the main studies identified on types of packaging used to prevent lipid oxidation.

Table 3. Packaging to prevent lipid oxidation.

\begin{tabular}{|c|c|c|c|c|}
\hline $\begin{array}{c}\text { Type of } \\
\text { packaging }\end{array}$ & Approach & Product & Result & Reference \\
\hline $\begin{array}{l}\text { Modified } \\
\text { atmosphere }\end{array}$ & $\begin{array}{l}\text { 1- }(\mathrm{HiOx}-\mathrm{MAP}): 80 \% \mathrm{O}_{2} \text { and } 20 \% \\
\mathrm{CO}_{2 ;} \\
2-\mathrm{CO}_{2}-\mathrm{MAP}: 20 \% \mathrm{CO}_{2} \text { and } 80 \% \mathrm{~N}_{2}\end{array}$ & $\begin{array}{l}\text { Lamb meat } \\
\text { (Ovis aries) }\end{array}$ & $\begin{array}{l}\text { The HiOx-MAP packaging negatively } \\
\text { influenced meat quality. It increased surface } \\
\text { discoloration and lipid oxidation, and led to } \\
\text { loss of aroma and flavor compared to } \mathrm{CO}_{2} \\
\text { packaging. The study suggests that the } \mathrm{CO}_{2}^{-} \\
\text {MAP packaging can reduce lipid oxidation } \\
\text { without compromising the visual aspect of the } \\
\text { product. }\end{array}$ & $\begin{array}{l}\text { Kim et al. } \\
(2013 b)\end{array}$ \\
\hline Vacuum & $\begin{array}{l}1 \text { - Control (conventional packaging) } \\
2 \text { - Vacuum packaging }\end{array}$ & $\begin{array}{c}\text { Ground goat meat } \\
\text { and goat meat } \\
\text { nuggets }\end{array}$ & $\begin{array}{l}\text { Packaging reduced TBARS by } 27 \% \text { in the } \\
\text { ground meat and by } 17 \% \text { in the nuggets. }\end{array}$ & $\begin{array}{l}\text { Devatkal et al. } \\
\quad(2014)\end{array}$ \\
\hline $\begin{array}{l}\text { Vacuum and } \\
\text { Modified } \\
\text { atmosphere }\end{array}$ & $\begin{array}{l}\text { 1- Vacuum } \\
\text { 2- MAP; } 25 \% \mathrm{CO}_{2}+75 \% \mathrm{~N}_{2}\end{array}$ & $\begin{array}{l}\text { Cured pork neck } \\
\text { (Sus domesticus) }\end{array}$ & $\begin{array}{l}\text { Meat packaged under modified atmosphere } \\
\text { showed higher lipid oxidation but lower } \\
\text { bacteria count. }\end{array}$ & $\begin{array}{l}\text { Kim et al. } \\
(2013 a)\end{array}$ \\
\hline $\begin{array}{l}\text { Modified } \\
\text { atmosphere }\end{array}$ & 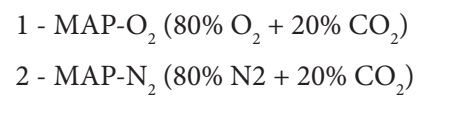 & $\begin{array}{l}\text { Broiler breast and } \\
\text { thigh (Gallus gallus } \\
\quad \text { domesticus) }\end{array}$ & $\begin{array}{l}\text { Chicken breast stored in } \mathrm{MAP}_{-} \mathrm{O}_{2} \text { clearly scored } \\
\text { higher in rancidity, than chicken thigh. }\end{array}$ & $\begin{array}{l}\text { Jongberg et al. } \\
\qquad(2014)\end{array}$ \\
\hline Vacuum & $\begin{array}{l}1 \text { - Oxygen- permeable film } \\
2 \text { - Vacuum packing in } \\
\text { oxygen-impermeable films }\end{array}$ & $\begin{array}{l}\text { Raw broiler meat } \\
\text { (Gallus gallus } \\
\text { domesticus) }\end{array}$ & $\begin{array}{l}\text { Vacuum packaging minimized lipid and protein } \\
\text { oxidation. }\end{array}$ & $\begin{array}{l}\text { Xiao et al. } \\
\text { (2011) }\end{array}$ \\
\hline $\begin{array}{l}\text { Antioxidant } \\
\text { active packaging }\end{array}$ & $\begin{array}{l}\text { Packaging with oregano extract } \\
\text { (Origanum vulgare) } \\
1-0.5 \% \\
2-1 \% \\
3-2 \% \\
4-4 \%\end{array}$ & $\begin{array}{l}\text { Beef sirloin } \\
\text { (Bos taurus) }\end{array}$ & $\begin{array}{l}\text { Active packaging containing } 1 \% \text { of oregano } \\
\text { extract significantly improved the oxidative } \\
\text { stability of the product. However, the packaging } \\
\text { containing } 4 \% \text { of oregano extract imparted an } \\
\text { unacceptable oregano odor to the meat. }\end{array}$ & $\begin{array}{l}\text { Camo et al. } \\
\text { (2011) }\end{array}$ \\
\hline $\begin{array}{l}\text { Antioxidant } \\
\text { active packaging }\end{array}$ & $\begin{array}{l}\text { Antioxidant film with extracts of } \\
\text { beer industry resid ues (phenolic } \\
\text { compounds) }\end{array}$ & Beef (Bos taurus) & $\begin{array}{l}\text { Antioxidant films coated with the extracts } \\
\text { reduced lipid oxidation by } 80 \% \text { compared to the } \\
\text { control. }\end{array}$ & $\begin{array}{l}\text { Pereira et al. } \\
\qquad(2015)\end{array}$ \\
\hline
\end{tabular}




\section{Conclusions}

Lipid oxidation is a complex process with great impact on the sensory quality of meat and meat products. The mechanisms of lipid oxidation in muscle and meat should be better investigated and understood in order to develop new approaches for its control and improve the existing methods. Although lipid peroxidation in meat has been, and will continue to be, a widely investigated topic, many of the factors and mechanisms involved in this reaction have not yet been completely clear.

For effective prevention of lipid oxidation, a lot of factors must be considered. The oxidative stability of meat can be maximized with appropriate pre-slaughter intervention strategies, such as a diet supplemented with $\alpha$-tocopherol and other antioxidants and maintaining an environment free of oxidative stress sources. During processing, the use of less pro-oxidant methods will positively affect the final product, for example, processes that do not expose the meat to extremely high temperatures, maintain meat integrity, use little sodium, and include the addition of antioxidants. Finally, during storage, the use of low temperatures and packaging that does not expose the meat to oxygen and light help extend shelf life by retarding the progression of lipid oxidation.

The use of natural antioxidants for the increased oxidative stability of meat is a topic of great interest today. Although an extensive range of natural products, such as antioxidants, have shown promising results, many of the sources used may contain toxic and antinutritional factors and can have negative effects if used in large amounts. Therefore, there is need for further studies to characterize active compounds in these natural sources and assess their effectiveness, safety, and stability in different amounts and different products.

\section{References}

Ahmad, H., Tian, J., Wang, J., Khan, M. A., Wang, Y., Zhang, L., \& Wang, T. (2012). Effects of dietary sodium selenite and selenium yeast on antioxidant enzyme activities and oxidative stability of chicken breast meat. Journal of Agricultural and Food Chemistry, 60(29), 7111-7120. http://dx.doi.org/10.1021/jf3017207. PMid:22732007.

Ahmed, S. T., Islam, M., Bostami, A. B. M. R., Mun, H., Kim, Y., \& Yang, C. (2015). Meat composition, fatty acid profile and oxidative stability of meat from broilers supplemented with pomegranate (Punica granatum L.) by products. Food Chemistry, 188, 481-488. http://dx.doi.org/10.1016/j.foodchem.2015.04.140. PMid:26041221.

Almeida, P. L., Lima, S. N., Costa, L. L., Oliveira, C. C., Damasceno, K. A., Santos, B. A., \& Campagnol, P. C. (2015). Effect of jabuticaba peel extract on lipid oxidation, microbial stability and sensory properties of Bologna-type sausages during refrigerated storage. Meat Science, 110, 9-14. http://dx.doi.org/10.1016/j.meatsci.2015.06.012. PMid:26156583.

Alvarez-Parrilla, E., Mercado-Mercado, G., La Rosa, L. A. D., Díaz, J. A. L., Wall-Medrano, A., \& González-Aguilar, G. A. (2014). Antioxidant activity and prevention of pork meat lipid oxidation using traditional Mexican condiments (pasilla dry pepper, achiote, and mole sauce). Food Science and Technology (Campinas), 34(2), 371-378. http://dx.doi.org/10.1590/fst.2014.0052.

Bekhit, A. E.-D. A., Hopkins, D. L., Fahri, F. T., \& Ponnampalam, E. N. (2013). Oxidative processes in muscle systems and fresh meat: sources, markers, and remedies. Comprehensive Reviews in Food Science and Food Safety, 12(5), 565-597. http://dx.doi. org/10.1111/1541-4337.12027.

Bolumar, T., Andersen, M. L., \& Orlien, V. (2011). Antioxidant active packaging for chicken meat processed by high pressure treatment. Food Chemistry, 129(4), 1406-1412. http://dx.doi.org/10.1016/j. foodchem.2011.05.082.

Boon, C. S., McClements, D. J., Weiss, J., \& Decker, E. A. (2009). Role of iron and hydroperoxides in the degradation of lycopene in oil-inwater emulsions. Journal of Agricultural and Food Chemistry, 57(7), 2993-2998. http://dx.doi.org/10.1021/jf803747j. PMid:19265448.

Brøndum, J., Byrne, D. V., Bak, L. S., Bertelsen, G., \& Engelsen, S. B. (2000). Warmed-over flavour in porcine meat - a combined spectroscopic, sensory and chemometric study. Meat Science, 54(1), 83-95. http:// dx.doi.org/10.1016/S0309-1740(99)00085-6. PMid:22063716.

Byrne, D. V., Bredie, W. L., Mottram, D. S., \& Martens, M. (2002). Sensory and chemical investigations on the effect of oven cooking on warmed-over flavour development in chicken meat. Meat Science, 61(2), 127-139. http://dx.doi.org/10.1016/S0309-1740(01)00171-1. PMid:22064001.

Camo, J., Lores, A., Djenane, D., Beltran, J. A., \& Roncales, P. (2011). Display life of beef packaged with an antioxidant active film as a function of the concentration of oregano extract. Meat Science, 88(1), 174-178. http://dx.doi.org/10.1016/j.meatsci.2010.12.019. PMid:21236591.

Cross, D. E., McDevitt, R. M., Hillman, K., \& Acamovic, T. (2007). The effect of herbs and their associated essential oils on performance, dietary digestibility, and gut microflora in chickens from 7 to 28 days of age. Brazilian Journal of Poultry Science., 48(4), 496-506. http://dx.doi.org/10.1080/00071660701463221. PMid:17701503.

Cullere, M., Hoffman, L. C., \& Zotte, A. D. (2013). First evaluation of unfermented and fermented rooibos (Aspalathus linearis) in preventing lipid oxidation in meat products. Meat Science, 95(1), 72 77. http://dx.doi.org/10.1016/j.meatsci.2013.04.018. PMid:23659927.

Daley, C. A., Abbott, A., Doyle, P. S., Nader, G. A., \& Larson, S. (2010). A review of fatty acid profiles and antioxidant content in grassfed and grain-fed beef. Nutrition Journal, 9(1), 10. http://dx.doi. org/10.1186/1475-2891-9-10. PMid:20219103.

Delles, R. M., Xiong, Y. L., True, A. D., Ao, T., \& Dawson, K. A. (2014). Dietary antioxidant supplementation enhances lipid and protein oxidative stability of chicken broiler meat through promotion of antioxidant enzyme activity. Poultry Science, 93(6), 1561-1570. http:// dx.doi.org/10.3382/ps.2013-03682. PMid:24879706.

Descalzo, A. M., \& Sancho, A. M. (2008). A review of natural antioxidants and their effects on oxidative status, odor and quality of fresh beef produced in Argentina. Meat Science, 79(3), 423-436. http://dx.doi. org/10.1016/j.meatsci.2007.12.006. PMid:22062902.

Devatkal, S. K., Thorat, P., \& Manjunatha, M. (2014). Effect of vacuum packaging and pomegranate peel extract on quality aspects of ground goat meat and nuggets. Journal of Food Science and Technology, 51(10), 2685-2691. http://dx.doi.org/10.1007/s13197-012-0753-5. PMid:25328212.

Ding, Y., Wang, S. Y., Yang, D. J., Chang, M. H., \& Chen, Y. C. (2015). Alleviative effects of litchi (Litchi chinensis Sonn.) flower on lipid peroxidation and protein degradation in emulsified pork meatballs. Journal of food and drug analysis, 23(3), 501-508. PMid:28911709.

Domenech-Asensi, G., García-Alonso, F. J., Martínez, E., Santaella, M., Martín-Pozuelo, G., Bravo, S., \& Periago, M. J. (2013). Effect of the addition of tomato paste on the nutritional and sensory properties of mortadella. Meat Science, 93(2), 213-219. http://dx.doi.org/10.1016/j. meatsci.2012.08.021. PMid:22999311. 
Duthie, G., Campbell, F., Bestwick, C., Stephen, S., \& Russell, W. (2013). Antioxidant effectiveness of vegetable powders on the lipid and protein oxidative stability of cooked turkey meat patties: Implications for health. Nutrients, 5(4), 1241-1252. http://dx.doi.org/10.3390/ nu5041241. PMid:23595133.

Emami, A., Nasri, M. H., Ganjkhanlou, M., Zali, A., \& Rashidi, L. (2015). Effects of dietary pomegranate seed pulp on oxidative stability of kid meat. Meat Science, 104, 14-19. http://dx.doi.org/10.1016/j. meatsci.2015.01.016. PMid:25681560.

Estevez, M. (2015). Oxidative damage to poultry: from farm to fork. Poultry Science, 94(6), 1368-1378. http://dx.doi.org/10.3382/ps/ pev094. PMid:25825786.

Faine, L. A., Rodrigues, H. G., Galhardi, C. M., Ebaid, G. M. X., Diniz, Y. S., Fernandes, A. A. H., \& Novelli, H. G. (2006). Butyl hydroxytoluene (BHT)-induced oxidative stress: Effects on serum lipids and cardiac energy metabolism in rats. Experimental and Toxicologic Pathology, 57(3), 221-226. http://dx.doi.org/10.1016/j. etp.2005.10.001. PMid:16338125.

Fasseas, M. K., Mountzouris, K. C., Tarantilis, P. A., Polissiou, M., \& Zervas, G. (2008). Antioxidant activity in meat treated with oregano and sage essential oils. Food Chemistry, 106(3), 1188-1194. http:// dx.doi.org/10.1016/j.foodchem.2007.07.060.

Font-I-Furnols, M. F., \& Guerrero, L. (2014). Consumer preference, behavior and perception about meat and meat products: An overview. Meat Science, 98(3), 361-371. http://dx.doi.org/10.1016/j. meatsci.2014.06.025. PMid:25017317.

Gallo, M., Ferracane, R., \& Naviglio, D. (2012). Antioxidant addition to prevent lipid and protein oxidation in chicken meat mixed with supercritical extracts of Echinacea angustifolia. The Journal of Supercritical Fluids, 72, 198-204. http://dx.doi.org/10.1016/j. supflu.2012.08.006.

Georgantelis, D., Ambrosiadis, I., Katikou, P., Blekas, G., \& Georgakis, S. A. (2007). Effect of rosemary extract, chitosan and $\alpha$-tocopherol on microbiological parameters and lipid oxidation of fresh pork sausages stored at $4^{\circ} \mathrm{C}$. Meat Science, 76(1), 172-181. http://dx.doi. org/10.1016/j.meatsci.2006.10.026. PMid:22064204.

González, E., \& Tejeda, J. F. (2007). Effects of dietary incorporation of different antioxidant extracts and free-range rearing on fatty acid composition and lipid oxidation of Iberian pig meat. Animal, 1(7), 1060-1067. http://dx.doi.org/10.1017/S1751731107000195. PMid:22444809.

Habibian, M., Ghazi, S., \& Moeini, M. M. (2016). Effects of dietary selenium and vitamin e on growth performance, meat yield, and selenium content and lipid oxidation of breast meat of broilers reared under heat stress. Biological Trace Element Research, 169(1), 142152. http://dx.doi.org/10.1007/s12011-015-0404-6. PMid:26085059.

Ismail, I. B. K., Al-Busadah, A., \& El-Bahr, S. M. (2013). Oxidative stress biomarkers and biochemical profile in broilers chicken fed zinc bacitracin and ascorbic acid under hot climate. American Journal of Biochemistry and Molecular Biology., 3(2), 202-214. http://dx.doi. org/10.3923/ajbmb.2013.202.214.

Jia, N., Kong, B., Liu, Q., Diao, X., \& Xia, X. (2012). Antioxidant activity of black currant (Ribes nigrum $\mathrm{L}$.) extract and its inhibitory effect on lipid and protein oxidation of pork patties during chilled storage. Meat Science, 91(4), 533-539. http://dx.doi.org/10.1016/j. meatsci.2012.03.010. PMid:22483714.

Jongberg, S., Wen, J., Tørngren, M. A., \& Lund, M. N. (2014). Effect of high-oxygen atmosphere packaging on oxidative stability and sensory quality of two chicken muscles during chill storage. Food Packaging and Shelf Life, 1(1), 38-48. http://dx.doi.org/10.1016/j. fpsl.2013.10.004.
Kahraman, T., Issa, G., Bingol, E. B., Kahraman, B. B., \& Dumen, E. (2015). Effect of rosemary essential oil and modified-atmosphere packaging (MAP) on meat quality and survival of pathogens in poultry fillets. Brazilian Journal of Microbiology, 46(2), 591-599. http://dx.doi.org/10.1590/S1517-838246220131201. PMid:26273279.

Karpińska-Tymoszczyk, M. (2014). The effect of antioxidants, packaging type and frozen storage time on the quality of cooked turkey meatballs. Food Chemistry, 148, 276-283. http://dx.doi.org/10.1016/j. foodchem.2013.10.054. PMid:24262557.

Kim, S. J., Cho, A. R., \& Han, J. (2013a). Antioxidant and antimicrobial activities of leafy green vegetable extracts and their applications to meat product preservation. Food Control, 29(1), 112-120. http:// dx.doi.org/10.1016/j.foodcont.2012.05.060.

Kim, Y. H., Stuart, A., Rosenvold, K., \& Maclennan, G. (2013b). Effect of forage and retail packaging types on meat quality of long-term chilled lamb loins. Journal of Animal Science, 91(12), 5598-6780. http://dx.doi.org/10.2527/jas.2013-6780. PMid:24085415.

Kiokias, S., Dimakou, C., \& Oreopoulou, V. (2009). Activity of natural carotenoid preparations against the autoxidative deterioration of sunflower oil-in-water emulsions. Food Chemistry, 114(4), 12781284. http://dx.doi.org/10.1016/j.foodchem.2008.10.087.

Kumar, Y., Yadav, D. N., Ahmad, T., \& Narsaiah, K. (2015). Recent Trends in the Use of Natural Antioxidants for Meat and Meat Products. Comprehensive Reviews in Food Science and Food Safety, 14(6), 796-812. http://dx.doi.org/10.1111/1541-4337.12156.

Laguerre, M., Lecomte, J., \& Villeneuve, P. (2007). Evaluation of the ability of antioxidants to counteract lipid oxidation: existing methods, new trends and challenges. Progress in Lipid Research, 46(5), 244-282. http://dx.doi.org/10.1016/j.plipres.2007.05.002. PMid:17651808.

Leal, R. S., Cantarelli, V. S., Mattos, B. O., Carvalho, G. C., Pimenta, M. E. S., \& Pimenta, C. J. (2014). Qualidade da carne de suínos submetidos a dietas com diferentes nivéis de ractopamina. Archivos de Zootecnia, 63(243), 507-518. http://dx.doi.org/10.4321/S000405922014000300011.

Li, Y., \& Liu, S. (2012). Reducing lipid peroxidation for improving colour stability of beef and lamb: on-farm considerations. Journal of the Science of Food and Agriculture, 92(4), 719-726. http://dx.doi. org/10.1002/jsfa.4715. PMid:22102139.

Lima, D. M.; Rangel, A.; Urbano, S.; Mitzi, G.; Moreno, G.M. (2013). Oxidação lipídica da carne ovina. Acta Veterinaria Brasilica, 7(1), $14-28$.

Liu, S. M., Sun, H. X., Jose, C., Murray, A., Sun, Z. H., Briegel, J. R., Jacob, R., \& Tan, Z. L. (2011). Phenotypic blood glutathione concentration and selenium supplementation interactions on meat colour stability and fatty acid concentrations in Merino lambs. Meat Science, 87(2), 130-139. http://dx.doi.org/10.1016/j.meatsci.2010.09.011. PMid:20951501.

Loetscher, Y., Kreuzer, M., \& Messikommer, R. E. (2013). Oxidative stability of the meat of broilers supplemented with rosemary leaves, rosehip fruits, chokeberry pomace, and entire nettle, and effects on performance and meat quality. Poultry Science, 92(11), 2938-2948. http://dx.doi.org/10.3382/ps.2013-03258. PMid:24135598.

Lorenzo, J. M., \& Gomez, M. (2012). Shelf life of fresh foal meat under MAP, overwrap and vacuum packaging conditions. Meat Science, 92(4), 610-618. http://dx.doi.org/10.1016/j.meatsci.2012.06.008. PMid:22749431.

Mercadante, A. Z., Capitani, C. D., Decker, E. A., \& Castro, I. A. (2010). Effect of natural pigments on the oxidative stability of sausages stored under refrigeration. Meat Science, 84(4), 718-726. http://dx.doi. org/10.1016/j.meatsci.2009.10.031. PMid:20374848. 
Mills, J., Donnison, A., \& Brightwell, G. (2014). Factors affecting microbial spoilage and shelf-life of chilled vacuum-packed lamb transported to distant markets: a review. Meat Science, 98(1), 71-80. http://dx.doi.org/10.1016/j.meatsci.2014.05.002. PMid:24875594.

Min, B., \& Ahn, U. (2005). Mechanism of lipid peroxidation in meat and meat products - a review. Food Science and Biotechnology, $14(1), 152-163$.

Min, B., Cordray, J., \& Ahn, D. U. (2010). Effect of NaCl, myoglobin, $\mathrm{Fe}(\mathrm{II})$, and $\mathrm{Fe}$ (III) on lipid oxidation of raw and cooked chicken breast and beef loin. Journal of Agricultural and Food Chemistry, 58(1), 600-605. http://dx.doi.org/10.1021/jf9029404. PMid:19904983.

Min, B., Nam, K. C., Cordray, J., \& Ahn, D. U. (2008). Endogenous factors affecting oxidative stability of beef loin, pork loin, and chicken breast and thigh meats. Journal of Food Science, 73(6), 439-446. http://dx.doi.org/10.1111/j.1750-3841.2008.00805.x. PMid:19241532.

Mohamed, H. M., Mansour, H. A., \& Farag, M. D. (2011). The use of natural herbal extracts for improving the lipid stability and sensory characteristics of irradiated ground beef. Meat Science, 87(1), 33-39. http://dx.doi.org/10.1016/j.meatsci.2010.06.026. PMid:20855173.

Munchweti, M., Kativu, E., Mupure, C. H., Chidewe, C., Ndhala, A.R., Benhura, M.A.N. (2007). Phenolic composition and antioxidant properties of some spices. American Journal of Food Technology., 2(5), 414-420. http://dx.doi.org/10.3923/ajft.2007.414.420.

O'Sullivan, M. G., Le Floch, S., \& Kerry, J. P. (2015). Resting of MAP (modified atmosphere packed) beef steaks prior to cooking and effects on consumer quality. Meat Science, 101, 13-18. http://dx.doi. org/10.1016/j.meatsci.2014.10.030. PMid:25462377.

Ortuño, J., Serrano, R., \& Bañón, S. (2015). Antioxidant and antimicrobial effects of dietary supplementation with rosemary diterpenes (carnosic acid and carnosol) vs vitamin $\mathrm{E}$ on lamb meat packed under protective atmosphere. Meat Science, 110, 62-69. http://dx.doi.org/10.1016/j. meatsci.2015.07.011. PMid:26186399.

Pereira, J. A., Dionisio, L., Patarata, L., \& Matos, T. J. (2015). Effect of packaging technology on microbiological and sensory quality of a cooked blood sausage, Morcela de Arroz, from Monchique region of Portugal. Meat Science, 101, 33-41. http://dx.doi.org/10.1016/j. meatsci.2014.09.147. PMid:25462380.

Price, A., Diaz, P., Banon, S., \& Garrido, M. D. (2013). Natural extracts versus sodium ascorbate to extend the shelf life of meat-based readyto-eat meals. Food Science \& Technology International, 19(5), 427438. http://dx.doi.org/10.1177/1082013212455345. PMid:23729424.

Radha, K., Babuskin, S., Azhagu, S. B. P., Sasikala, M., Sabina, K., Archana, G., Sivarajan, M., \& Sukmar, M. (2014). Antimicrobial and antioxidant effects of spice extracts on the shelf life extension of raw chicken meat. International Journal of Food Microbiology, 171, 32-40. http://dx.doi.org/10.1016/j.ijfoodmicro.2013.11.011. PMid:24308943.

Realini, C. E., Guardia, M. D., Diaz, I., Garcia-Regueiro, J. A., \& Arnau, J. (2015). Effects of acerola fruit extract on sensory and shelf-life of salted beef patties from grinds differing in fatty acid composition. Meat Science, 99, 18-24. http://dx.doi.org/10.1016/j. meatsci.2014.08.008. PMid:25280358.

Rhee, K. S., \& Ziprin, Y. A. (2001). Pro-oxidant effects of $\mathrm{NaCl}$ in microbial growth-controlled and uncontrolled beef and chicken. Meat Science, 57(1), 105-112. http://dx.doi.org/10.1016/S03091740(00)00083-8. PMid:22061173.

Rojas, M. C., \& Brewer, M. S. (2008). Effect of natural antioxidants on oxidative stability of frozen, vacuum-packaged beef and pork. Journal of Food Quality, 3(12), 173-188. http://dx.doi.org/10.1111/j.17454557.2008.00196.x.
Sampaio, G. R., Saldanha, T., Soares, R. A. M., \& Torres, E. A. F. S. (2012). Effect of natural antioxidant combinations on lipid oxidation in cooked chicken meat during refrigerated storage. Food Chemistry, 135(3), 1383-1390. http://dx.doi.org/10.1016/j.foodchem.2012.05.103. PMid:22953870.

Selani, M. M., Contreras-Castillo, C. J., Shirahigue, L. D., Gallo, C. R., Plata-Oviedo, M., \& Montes-Villanueva, N. D. (2011). Wine industry residues extracts as natural antioxidants in raw and cooked chicken meat during frozen storage. Meat Science, 88(3), 397-403. http://dx.doi.org/10.1016/j.meatsci.2011.01.017. PMid:21342750.

Shah, M. A., Bosco, S. J., \& Mir, S. A. (2014). Plant extracts as natural antioxidants in meat and meat products. Meat Science, 98(1), 21-33. http://dx.doi.org/10.1016/j.meatsci.2014.03.020. PMid:24824531.

Shaheen, M. S., Shaaban, H. A., Hussein, A. M. S., Ahmed, M. B. M., El-Massry, K., \& El-Ghorab, A. (2016). Evaluation of chitosan/ fructose model as an antioxidant and antimicrobial agent for shelf life extension of beef meat during freezing. Polish Journal of Food and Nutrition Sciences, 66(4), 295-302. http://dx.doi.org/10.1515/ pjfns-2015-0054.

Silva, S., Pacheco, G. D., Vinokurovas, S. L., Oliveira, E. R., Gavioli, D. F., Lozano, A. P., Agostini, P. S., Bridi, A. M., \& Silva, C. A. (2015). Associação de ractopamina e vitaminas antioxidantes para suínos em terminação. Ciência Rural, 45(2), 311-316. http://dx.doi. org/10.1590/0103-8478cr20140048.

Srinvasan, D., Parkin, K. L., \& Fennema, O. R. (2008). Fennema's food chemistry (4th ed.). Boca Raton: CRC Press.

Starčević, K., Krstulović, L., Brozić, D., Maurić, M., Stojević, Z., Mikulec, Ž., Bajić, M., \& Mašek, T. (2015). Production performance, meat composition and oxidative susceptibility in broiler chicken fed with different phenolic compounds. Journal of the Science of Food and Agriculture, 95(6), 1172-1178. http://dx.doi.org/10.1002/jsfa.6805. PMid:24995966.

Surai, P. F., \& Fisinin, V. I. (2014). Selenium in poultry breeder nutrition: an update. Animal Feed Science and Technology, 191, 1-15. http:// dx.doi.org/10.1016/j.anifeedsci.2014.02.005.

Tres, A., Bou, R., Codony, R., \& Guardiola, F. (2010). Moderately oxidized oils and dietary zinc and a-tocopheryl acetate supplementation: effects on the oxidative stability of rabbit plasma, liver, and meat. Journal of Agricultural and Food Chemistry, 58(16), 9112-9119. http://dx.doi.org/10.1021/jf101635b. PMid:20681580.

Uenojo, M., Maróstica, M. R. Jr., \& Pastore, G. M. (2007). Carotenóides: propriedades, aplicações e biotransformação para formação de compostos de aroma. Quimica Nova, 30(3), 616-622. http://dx.doi. org/10.1590/S0100-40422007000300022.

Universidade Federal do Rio de Janeiro - UFRJ. (2013). Bromatologia em Saúde - Estudos e pesquisas dos alunos da disciplina Bromatologia em Saúde oferecida pela Faculdade de Farmácia da UFRJ: será a ractopamina a vilã da carne brasileira? Rio de Janeiro: UFRJ. Retrieved from: http://bromatopesquisas-ufrj.blogspot.com.br/2013/01/seraractopamina-vila-da-carne.html

Vaithiyanathan, S., Naveena, B. M., Muthukumar, M., Girish, P. S., \& Kondaiah, N. (2011). Effect of dipping in pomegranate (Punica granatum) fruit juice phenolic solution on the shelf life of chicken meat under refrigerated storage $4^{\circ} \mathrm{C}$. Meat Science, 88(3), 409-414. http://dx.doi.org/10.1016/j.meatsci.2011.01.019. PMid:21345604.

Van Hecke, T., Van Camp, J., \& Smet, S. (2017). Oxidation during digestion of meat: interactions with the diet and Helicobacter pylori Gastritis, and implications on human health. Comprehensive Reviews in Food Science and Food Safety, 16(2), 214-233. http://dx.doi. org/10.1111/1541-4337.12248. 
Velasco, V., \& Williams, P. (2011). Improving meat quality through natural antioxidants. Chilean Journal of Agricultural Research, 71(2), 313-322. http://dx.doi.org/10.4067/S0718-58392011000200017.

Vossen, E., Ntawubizi, M., Raes, K., Smet, K., Huyghebaert, G., Arnouts, S., \& Smet, S. (2011). Effect of dietary antioxidant supplementation on the oxidative status of plasma in broilers. Journal of Animal Physiology and Animal Nutrition, 95(2), 198-205. http://dx.doi. org/10.1111/j.1439-0396.2010.01041.x. PMid:20796081.

Wójciak, K. M., \& Dolatowski, Z. J. (2012). Oxidative stability of fermented meat products. Acta Scientiarum Polonorum. Technologia Alimentaria, 11(2), 99-109. PMid:22493153.

Wu, B., Cui, H., Peng, X., Fang, J., Zuo, Z., Deng, J., \& Huang, J. (2013). Investigation of the serum oxidative stress in broilers fed on diets supplemented with nickel chloride. Health, 5(03), 454-459. http:// dx.doi.org/10.4236/health.2013.53061.

Xiao, S., Zhang, W. G., Lee, E. J., Ma, C. W., \& Ahn, D. U. (2011). Effects of diet, packaging, and irradiation on protein oxidation, lipid oxidation, and color of raw broiler thigh meat during refrigerated storage. Poultry Science, 90(6), 1348-1357. http://dx.doi.org/10.3382/ ps.2010-01244. PMid:21597078.

Zhang, W., Xiao, S., Lee, E. J., \& Ahn, D. U. (2011). Consumption of oxidized oil increases oxidative stress in broilers and affects the quality of breast meat. Journal of Agricultural and Food Chemistry, 59(3), 969-974. http://dx.doi.org/10.1021/jf102918z. PMid:21192702.

Zhao, X., Yang, Z. B., Yang, W. R., Wang, Y., Jiang, S. Z., \& Zhang, G. G. (2011). Effects of ginger root (Zingiber officinale) on laying performance and antioxidant status of laying hens and on dietary oxidation stability. Poultry Science, 90(8), 1720-1727. http://dx.doi. org/10.3382/ps.2010-01280. PMid:21753209.

Zhou, H.-C., Lin, Y.-M., Li, Y.-Y., Li, M., Wei, S.-D., Chai, W.-M., \& Tam, N. F. (2011). Antioxidant properties of polymeric proanthocyanidins from fruit stones and pericarps of Litchi chinensis Sonn. Food Research International, 44(2), 613-620. http://dx.doi.org/10.1016/j. foodres.2010.12.016. 